\title{
DEVELOPING COMMUNICATIVE LEARNING MATERIALS FOR TEACHING ENGLISH AS A FOREIGN LANGUAGE TO STUDENTS OF ELEMENTARY TEACHER EDUCATION STUDY PROGRAM OF FLORES UNIVERSITY OF EAST NUSA TENGGARA
}

\author{
M.K. Ota ${ }^{1}$, N.N. Padmadewi ${ }^{2}$, M.H. Santosa ${ }^{3}$ \\ ${ }^{123}$ English Language Education, Post Graduate Program, Universitas Pendidikan Ganesha, Singaraja \\ e-mail: kristina.ota@rocketmail.com, nym.padmadewi@undiksha.ac.id, mhsantosa@undiksha.ac.id
}

This study aimed at developing communicative learning materials for teaching English as a foreign language to students of elementary teacher education study program of Flores University. The instruments used in this study were observation sheet, interview guide, scoring rubric, and questionnaire which were used to gather data during product's development. This study used the research and development model proposed by Sugiyono (2009). The result shows that the developed communicative learning materials were relevant to the students' needs. The learning materials which were designed in the form of a textbook were relevant to the students' expertise and the developed materials which were used along with communicative activities were categorized as having good quality. The implementation of the communicative materials are effectively implemented in the classroom where the result of posttest mean score was 86 and pretest mean score was 75 . The lecturers of English in this study program are suggested to use these present communicative learning materials and various activities in order to avoid the boredom of the students during teaching and learning process. The various activities used can help learners to enhance their English abilities in communication and the students' improvements of English can be increased.

\section{Key words: Developing ELT materials, CLT, Communicative competence}

\section{INTRODUCTION}

Language is the most important medium of human communication and it cannot be separated from human daily life. People use language to express their ideas, create and interpret meanings, as well as establish and maintain social and interpersonal relationship.

Every human has an ability to learn language, both native and foreign languages. One of the foreign languages in Indonesia is English. Crystal (2005) stated that as a foreign language, English is used as a tool of communication among countries particularly in political, social, educational and economic development. As a foreign language, English plays an important role in school environment. The main aim of a learner learning English is to acquire the language itself and to use the language in communication. Communicative language teaching is a method to enable students to acquire a language which focuses on the development of communicative competence. Azri and Al-rashdi, (2014) stated that the most important tool a teacher can and must use in class in order to make his/her teaching go smoothly and effectively transmitting the necessary knowledge to all students is authentic material. Authentic materials in EFL class were started used by teachers in 1970s as a result of the spread of communicative language teaching. Authentic materials are related to CLT because they were produced for real life communicative purpose (Lee, 1995). It means that the use of authentic materials meets the CLT's goals of helping students to achieve communicative competence. In other word, authentic materials help learners experience communication in the target language. Freeman (2000) further stated that one of the characteristics of communicative language teaching is the use of authentic materials. CLT approach has changed a language from the language to be learned like other subjects in school, to very important tool of communication inside and outside the classroom (Freeman, 2000). In addition, Gilmore (2007) pointed out that authentic materials are necessary because they are major condition of CLT that require language expression of speakers' real world experiences. 
In the process of teaching and learning, the four language skills (listening, speaking, reading and writing) are simultaneously performed. The students will have good communicative competence and will get high level of achievement if they master the four skills of English (Liton, 2012). All students who study English have their own capacity to communicate their ideas, thoughts and feelings not only in a written way but also in an oral way. However, not all students have the same capacity to obtain specific levels in their own skills during English learning process. A communicative activity is an encouragement methods which is needed to increase the students' communicative competence and improve their skills in learning English. Implementing communicative activities is one of the effective ways to train students' abilities as well as for the teacher (Gao, 2008). Mary and Nirmala (2012) stated that a communicative activity tends to give the students opportunities to do more speaking and during a communicative exercise the students are active by leaving their seats to complete a task.

Considering the fact that in English teaching and learning process of students of elementary teacher education study program of Flores University, it can be stated that was still teacher centred. It showed that the teaching and learning process that was occurred in the classroom was still focused on teacher. It can be seen that just half of the students were actively involved during the learning process and the rest of them were just sitting, writing and listening to the teacher's explanation. The students just passively listen to the teacher. The teacher sometimes emphasized on the grammatical and reading skills, rather than communication. Meanwhile, the willingness of the students to participate in the classroom process decreased because of the difficulties to share their ideas and the lack of their confidences. It seemed like they just pretend to be silent during the learning process. Thus, the materials which were introduced by the lecturer were not interesting. She did not provide interesting pictures, videos, or songs. Learning period was spent copying from the blackboards, translating texts and vocabulary from English to Indonesia.

The teaching and learning processes running in the classroom have disengaged the students' involvement. The encouragement of the students was really limited. It means that the chance for the students to communicate, to express ideas and thoughts were not the main point. The students just put all of their focus on the teacher. Teacher was not creative in using various teaching methods. She could not make the classroom situation to be more fun and enjoyable during teaching and learning process. As the consequences, some students got bored, passive and disengaged. Regarding to those factors, this study was assigned to conduct a study on developing communicative learning materials of English used along with six communicative activities for teaching and learning English as a foreign language to students of elementary teacher education study program of Flores University.

\section{METHODS}

The design of this study was based on the Research and Development model proposed by Sugiyono (2009). This study was conducted at Flores University, especially at students of elementary teacher education study program. The subjects of this study were the second semester students of elementary teacher education study program because based on the curriculum, the English subject was taught in that semester. The two classes chosen as the samples of this study were class $A$ and class $B$.

The R\&D model generally consists of 10 steps, but because of the limited of the time, only 8 steps were conducted, they were:

\section{Step 1: Identifying the potential problems}

The identification of potential problems was done by conducting preliminary observation. It was conducted through classroom observation. It was done to know the problem faced both by the students in learning English and the lecturer during teaching and learning process. The problems were identified through questionnaires which were distributed to the students and interview guide which was given to the lecturer. 


\section{Step 2: Library research}

This procedure was done to get some related resources to gather the theory as the basis of completing this study. In this step, the research instruments such as questionnaire, interview guide and the blueprint for developing the product were also designed.

\section{Step 3: Product design}

The third step conducted after gaining data through classroom observation and library research. This step was conducted to design the communicative leaning material of English which were used along with six activities in the classroom. The English learning material and activities were made to be compatible to the needs of the students and fulfilled the criteria of effective strategy and criteria of good material.

\section{Step 4: Expert judgement}

After the product was designed, it was then given expert judgement. There were two experts in education involved in this stage as judges. The judges were asked to give a check mark in the instrument for "relevant" and "not relevant" content to indicate whether or not they agree with each item.

\section{Step 5: Revision}

This procedure was done by revising the product based on some comments and suggestion given by the two judges.

\section{Step 6: Field test}

In this procedure, the English learning material and the communicative activities were tried out. The field tests were conducted in 2 classes. One class was treated by giving the proposed English learning material and activities in real classroom meetings, while the other class was used as the control class. After that, to measure the effectiveness of the product provided, questionnaires were distributed.

\section{Step 7: Revision}

After the product was implemented, product revision was conducted. The revision was made based on the result of the questionnaires about the product effectiveness which were done by both to the students and the lecturer by putting some comments, criticism and suggestion. However, the result of the product implementation was good, thus, no revision was made.

\section{Step 8: Final product}

In this step, the final form of the material was presented. It has been revised and corrected by the judges. The students and the lecturer were also have given their feedbacks through the questionnaires in the field test.

Generally, the methods of data collection used in this study were observation and documentation, expert judgement, distributing questionnaires, interview, and field study. Meanwhile, the instruments used in this study were questionnaires, expert judgement sheet, and interview guide.

The gathered data then analyzed qualitatively and quantitatively. Inter-ratter agreement model was use to measure the content validity of the product, while for the data obtained from scoring rubrics was analyzed quantitatively. The inter-ratter formula is as stated below: 
Table 1. Inter-ratter Agreement Model for Content Validity (Adopted from Gregory, 2000)

\begin{tabular}{|c|c|}
\hline $\mathrm{C}(-+)$ & $\mathrm{D}(++)$ \\
\hline $\mathrm{B}(+-)$ & $\mathrm{A}(--)$ \\
\hline
\end{tabular}

Table 2. the Formula for Analyzing the Result of The Inter-ratter Agreement

$\frac{\mathrm{D}}{\mathrm{A}+\mathrm{B}+\mathrm{C}+\mathrm{D}}$

Table 3. the Quality of the Product

\begin{tabular}{|l|c|}
\hline \multicolumn{1}{|c|}{ Score } & Categories \\
\hline$\overline{\mathrm{x}} \geq \mathrm{Mi}+1.5 \mathrm{Sdi}$ & Excellent \\
\hline $\begin{array}{l}\mathrm{Mi}+0.5 \mathrm{Sdi} \leq \overline{\mathrm{x}}<\mathrm{Mi} \\
+1.5 \mathrm{Sdi}\end{array}$ & Good \\
\hline $\begin{array}{l}\mathrm{Mi}-0.5 \mathrm{Sdi} \leq \overline{\mathrm{x}}<\mathrm{Mi}+ \\
0.5 \mathrm{Sdi}\end{array}$ & Average \\
\hline $\begin{array}{l}\mathrm{Mi}-1.5 \mathrm{Sdi} \leq \overline{\mathrm{x}}<\mathrm{Mi} \\
-0.5 \mathrm{Sdi}\end{array}$ & Below average \\
\hline$\overline{\mathrm{x}}<\mathrm{Mi}-1.5 \mathrm{Sdi}$ & Poor \\
\hline
\end{tabular}

\section{FINDING AND DISCUSSION}

\section{COMMUNICATIVE LEARNING MATERIALS THAT SHOULD BE DEVELOPED FOR STUDENTS OF ELEMENTARY TEACHER EDUCATION}

The development of communicative learning material was done because of the English lecturer did not have a specific learning material to support students in learning English. It was needed to fulfil the students' needs and wants. In her teaching and learning, the lecturer usually used some guidance books as sources to facilitate her teaching. She got material for her teaching from those books. However, she did not prepare like handbook or her own textbook to support her teaching. She just taught and tried to finish all the materials. The students just copied from the slide show/blackboard all the materials taught by the lecturer.

The activities used by the lecturer were not varied. The English lecturer was not creative to make her teaching and learning to be more interactive. Based on classroom observation was done to obtain data on how existing materials were used in teaching, it was found that the learning materials used in the process of teaching and learning were not communicative. The games used by the lecturer were not interactive. It then gave impact to the classroom situations during teaching and learning English, the impact made the students became quieter and a little bit passive. It was proven when some students just sat and listened to the lecturers' explanations without participating.

Through the interview guide that was given to the English lecturer, she stated that she did not have specific learning material, just textbook or handbook as guidance book for the learners. She just made slide show presentation for teaching. The learners just copied from the blackboard or slide show. The material also was not communicative and the lecturer did not provide other media like pictures, videos, games, etc which will motivate students to learn English. The method used sometimes can be motivated but just half of the students were 
active to participate. It was not effective yet. She confessed that she should try other methods in order to make the students will never get bored during the lesson.

From the evidences mentioned which were stated above it can be concluded that the students of elementary teachers study program of Flores University need the communicative learning materials that can make them are active in communication during the process of teaching and learning. Thus, the classroom situation during the materials are implemented is far from quite, fun and enjoyable because the lecturer also used varied actiivities during the learning process. Further, the developed communicative learning materials also can help learners to enhance their abilities in communication and their improvement of English can be increased.

\section{DEVELOPING COMMUNICATIVE LEARNING MATERIALS FOR TEACHING ENGLISH TO STUDENTS OF ELEMENTARY TEACHER EDUCATION}

The materials had been developed consisted of four language skills, they are listening, speaking, reading and writing. The topics chosen were based on the curriculum of PGSD. Those topics are (1) greetings and introductions, (2) family and relationship, (3) date and time, (4) food and money, (5) transportations, and (6) jobs and routines.

Covering English learning material with a new knowledge will present good environment during the process of learning. Therefore, the main purpose of learning materials is to achieve the students' needs and wants. Wu (2009) stated that in communicative principle, authentic materials are considered desirable to give students an opportunity to develop strategies for understanding the language. Moreover, Vijayasri (2016) on her research found that the teacher have a positive attitude towards the use of authentic materials. The teacher felt that authentic materials can generate interest and provide opportunities to develop student's communicative skills. Thus, Padmadewi (2013) further expressed that the teachers are required to enrich themselves with special skills, knowledge and patience in order that students will feel comfort and enjoy their learning process in classroom.

The materials had been designed based on the theory proposed by Tomlinson (2013). There are some principles related to learning material development for teaching of language, they are: (1) materials should achieve impact (through novelty, variety, surprise, attractive presentation and appealing context), (2) materials should help learners to feel at ease, (3) materials should help learners to develop confidence, (4) what is being taught should be perceived by learners as relevant and useful. (5) materials should require and facilitate learners self-investment, (6) learners must be ready to acquire the points being taught both in terms of linguistic, developmental readiness and of psychological too, (7) materials should expose the learners to language in authentic use, (8) the learners' attention should be drawn to linguistic features of the input, (9) materials should provide the learners with opportunities to use the target language to achieve communicative purpose, (10) materials should take into account that learners differ in learning styles.

Howard and Major (1995) see that designing material is an important part to support students' teaching and learning. In this case, the teacher spent their time to find, select, adapt and make materials to use in their teaching. There are ten guidelines for designing effective English teaching materials, namely: (1) learning material should be contextualized, (2) learning material should stimulate interaction and be generative in terms of language, (3) learning material should encourage learners to develop their learning skills and strategies, (4) learning material should allows for a focus on form as well as function, (5) learning material should offer opportunities for integrated language use, (6) learning material should be authentic, (7) learning material should link each other to develop a progression of skills, understanding and language items, (8) learning material should be attractive, (9) learning material should have appropriate instructions, and (10) learning material should be flexible.

The quality of the learning material was seen from the validity of the material. It was found that the material for teaching and learning English was categorized as excellent material. It could be seen through the rubric. The first was from the rubric of good material 
which was filled by the judges. The rubric of good material consisted of three aspects. The first was about features of the book which could impact variety of activities that were used in teaching and learning English, such as; role play, information gap, sentence race, think talk write and snowball throwing. There were also attractive presentations. It can be seen from the learning material which involved colourful pictures and the design of the text book itself which could attract the students to read. In this aspect, no significant problem was found. The second aspect was about the book's content. It consisted of the consistencies of the pictures with the topic, the clear instruction, and the arrangement of the learning. In this aspect, it was found that the learning materials need to be more consistent in putting related pictures with the topic to avoid student's misunderstanding. There were also unclear instructions found in every exercise. The students would understand more about the material and easily do the exercises if the instruction was clear and not only instructions, but also examples which were needed as their guideline to understand the materials and do the exercise correctly. Further, the learning skills in learning materials were not well arranged, and the last aspect was the benefit of using the book. In this aspect, no significant problem was found. The learning materials being learnt could help students to develop their communicative competence and their confidences achieved through the activities or task in the textbook.

A product cannot be judged as having excellent quality when it was only seen from the contents involved. But it should be seen from other points as well such as validity (content and construct), practicality, and effectiveness of the product. Content validity is about theory/literature review gathered in preliminary observation while construct validity is about steps that had been conducted during the development of the product. Besides that, the product was based on the criteria of good EFL materials proposed by Tomlinson. In other words, it can be said that the researcher used some theories as the basis of the product development. The quality of the products in this study was shown by the result of expert judgement and also students' and teachers' questionnaires toward the product. The result of the expert judgement showed that the English learning materials were categorized as excellent materials since the calculation of the scales showed such in the following table:

Table 5. Result of Good Material Criteria

\begin{tabular}{|c|c|}
\hline Score & Criteria \\
\hline$X \geq 229.5$ & $\begin{array}{c}\text { Excellent } \\
\text { Material }\end{array}$ \\
\hline $178.5 \leq X<229.5$ & Good Material \\
\hline $127.5 \leq X<178.5$ & Average Material \\
\hline $76.5 \leq X<127.5$ & $\begin{array}{c}\text { Below Average } \\
\text { Material }\end{array}$ \\
\hline$X<76.5$ & Poor Material \\
\hline
\end{tabular}

It means that the English material have good quality to support students' to learn English.

The second rubric was about the judges checked the relevance of the items in the questionnaire with the blue print. These questionnaires then were given to the lecturer and the students in order to know their opinion regarding the materials being implemented in the classroom. The result showed that the quality of the material of English has a very high quality because the interval score was $0.76 \leq x \leq 1.00$. It means that the learning material has fulfilled the aspects in the materials evaluation. 
Table 6. Inter-rater Agreement Table for Materials Validation

\begin{tabular}{|c|c|}
\hline C (-+) & $\begin{array}{l}\mathrm{D}(++) \\
1,2,3,4,5,6,7,8,9,10,11, \\
12,13,14,15,16,17,18,19, \\
20,21,22,23,24,25,26,27, \\
28,29,30 .\end{array}$ \\
\hline $\mathrm{B}(+-)$ & A (--) \\
\hline
\end{tabular}

The total number of items in each box was calculated by using the following formula:

$$
\begin{aligned}
& C V=\frac{D}{A+B+C+D} \\
& C V=\frac{30}{30}=1.00
\end{aligned}
$$

Then, the result was converted into the following criteria:

Table 7. The Result Good Material Criteria

\begin{tabular}{|c|c|}
\hline Interval & Category \\
\hline $0.76 \leq \mathrm{x} \leq 1.00$ & $\begin{array}{c}\text { Very high } \\
\text { validity }\end{array}$ \\
\hline $0.59 \leq \mathrm{x}<0.76$ & High validity \\
\hline $0.42 \leq \mathrm{x}<0.59$ & Average validity \\
\hline $0.20 \leq \mathrm{x}<0.4$ & Low validity \\
\hline $0 \leq \mathrm{x}<0.20$ & Poor validity \\
\hline
\end{tabular}

Thus, to know the quality of learning materials for students of elementary teacher education of Flores University, it then tested by doing field test. The developed communicative learning materials which were supported by six activities were then implemented in real classroom in second semester students of elementary teacher education.

After the implementation, the questionnaires were administered both to the students and the lecturer. There were 30 items consisted in the questionnaires that were given to the lecturer as well as to the students. In general, statements given by the lecturer and the students, said that the product were acceptable and considered as a good product. The students also had the same comment regarding the product. The result from the questionnaires can be summarized that the product has fulfilled the learners need and relevant to their expertise. However, there were also suggestions related to the product, they are: (1) the difficult sentences should be replaced, so that the sentences could be understandable, (2) the questions should be replaced then arranged with easy, so that the students would do the exercises easily.

Meanwhile, the product also got positive response from the result of post-test. The result of the post-test showed that the students improved their English achievement in the process of the material implementation. There were 8 students $(29 \%)$ gained and increased 10 points, 6 students (21\%) increased more than 10 points and the rest were 14 students $(50 \%)$ gained an increased score less than 10 points. The result shown that the score of the post-test was higher than pre-test, where the mean score obtained was 86 and 75 . 
Table 8. the Result of Post-test of Students Elementary Teacher Education Study Program of Flores University

\begin{tabular}{|c|c|c|}
\hline No of students & $\begin{array}{l}\text { Pre- } \\
\text { Test } \\
\text { Score }\end{array}$ & $\begin{array}{l}\text { Post- } \\
\text { Test } \\
\text { Score }\end{array}$ \\
\hline Std 1 & 75 & 85 \\
\hline Std 2 & 70 & 80 \\
\hline Std 3 & 73 & 78 \\
\hline Std 4 & 70 & 75 \\
\hline Std 5 & 65 & 75 \\
\hline Std 6 & 80 & 92 \\
\hline Std 7 & 63 & 73 \\
\hline Std 8 & 76 & 85 \\
\hline Std 9 & 70 & 75 \\
\hline Std 10 & 76 & 81 \\
\hline Std 11 & 70 & 85 \\
\hline Std 12 & 65 & 75 \\
\hline Std 13 & 83 & 90 \\
\hline Std 14 & 73 & 81 \\
\hline Std 15 & 70 & 80 \\
\hline Std 16 & 80 & 85 \\
\hline Std 17 & 73 & 84 \\
\hline Std 18 & 70 & 80 \\
\hline Std 19 & 75 & 78 \\
\hline Std 20 & 70 & 73 \\
\hline Std 21 & 68 & 75 \\
\hline Std 22 & 73 & 83 \\
\hline Std 23 & 70 & 78 \\
\hline Std 24 & 72 & 85 \\
\hline Std 25 & 75 & 84 \\
\hline Std 26 & 67 & 78 \\
\hline Std 27 & 75 & 87 \\
\hline Std 28 & 70 & 87 \\
\hline Mean & 75 & 86 \\
\hline
\end{tabular}

It can be summarized that the product that was made could help students to improve their English achievement and efficiently implement it in the process of teaching and learning English for elementary teacher education's students. The same result was also conducted by Trianasari (2015). She stated that the new learning material got positive feedback from the students as well as the teacher and the students and it could be categorized as excellent materials.

\section{THE ACTIVITIES USED FOR TEACHING ENGLISH TO STUDENTS OF ELEMENTARY TEACHER EDUCATION}

Communicative activities have real purpose; for example, to find information, break down barriers, talk about themselves, and learn about the culture. When a lesson is focused on developing reading or writing skills, communicative activities should be integrated into the lesson (Ramos, 2012). It includes any activity that encourages and requires a learner to speak with and listen to other learners, as well as with people in the classroom. Gao (2008) stated that implementing communicative activities is one of the effective ways to train students' abilities and their absorption of knowledge. Moreover, the communicative activities can be said as an effective if they are properly implemented in classroom. Moss and Ross- 
Fieldman (2003) stated that communicative activities can help to turn an English classroom into active, safe, and enjoyable place where literacy and beginning level learners can learn what they need and want to learn. On the same view Ochoa, Cabrera, Quiñónez, Castillo, and González (2016) on their research found that communicative activities are motivating. Students feel confident when they help each other during the interaction in activities such as class discussion, games, pair work, role plays, and group oral presentation. According to Peng (2013), communicative activities have some benefits, such as (1) learners are exposed to more input, which allows them to connect form with function and meaning; (2) learners have more chance for output; and (3) increases the learners' chance to receive corrective feedback from their peers as well as from their teachers; (4) have more chance to modify their language.

The appropriate communicative activities which have been used for teaching and learning English for the students of elementary teacher education was based on the theory of Herrell and Jordan (2004). It was designed by considering to the weaknesses of previous activities. There are five underlying premises of effective instruction of each strategies proposed by Herrell and Jordan (2004), those premises are the following:(1) teacher should provide instruction in a way that ensures that students are given comprehensible input, (2) teacher should provide opportunities to increase verbal interaction in classroom activities, (3) teacher should provide instruction that contextualizes the language as much as possible, (4) teacher should use teaching strategies and grouping techniques that reduce of anxiety of the students as much as possible, (5) teacher should provide activities in the classroom that offer opportunities for active involvement of the students. The activities selected should best suit the learners' need. Those activities on this present research are: (1) role play, (2) information gap, (3) sentence race, (4) think talk write, (5) shadowing and (6) snowball throwing. The combination of the activities used during teaching and learning could support the teacher to plan innovative lesson, such will motivate the students to learn and support to acquiring English. Phisutthangkoon (2012) stated that by using communicative activities, it could create a relaxing atmosphere where students feel free to speak with their peers and their participation in the classroom would be supported. The activeness of learning activities could help the learners to develop their confidence. It means that, the materials provided by the activities could build the learners confidences by pushing them to engage in task, be more active and work collaboratively during the process of learning.

Providing students with various communicative activities in English teaching and learning is a great help for students to understand the target language and hoping that the students be able to communicate actively during learning process. The activities used hopefully can make the classroom more enjoyable, pleasant, and stimulating as well as make students feel motivated to learn the target language. Having an enjoyable classroom is a very positive thing for language learning because it will give the students more exposure to language input and more chance to practice the language. When creating a suitable atmosphere to learn in the EFL classroom any learner can learn the target language (Cakir, 2004).

Table 9. Inter-rater Agreement Table for the Students' Need Analysis Validation.

\begin{tabular}{|c|c|}
\hline $\mathbf{C ~ ( - + )}$ & $\mathbf{D}(++)$ \\
& $1,2,3,4,5,6,7,8,9,10,11,12,1$ \\
& $3,14,15,16,17,18,20,21,22$, \\
& $23,24,25,26,27,28,29,30$ \\
\hline $\mathbf{B}(+-)$ & $\mathbf{A ~ ( - - )}$ \\
\hline
\end{tabular}


The total item was calculated using the following formula:

$$
\begin{aligned}
& C V=\frac{D}{A+B+C+D} \\
& C V=\frac{30}{30}=\mathbf{1 . 0 0}
\end{aligned}
$$

The result of the calculation was converted into the following criteria.

Table 10. The Result Good Material Criteria

\begin{tabular}{|l|l|}
\hline \multicolumn{1}{|c|}{ Interval } & \multicolumn{1}{c|}{ Category } \\
\hline $0.76 \leq x \leq 1.00$ & Very high validity \\
\hline $0.59 \leq x<0.76$ & High validity \\
\hline $0.42 \leq x<0.59$ & Average validity \\
\hline $0.20 \leq x<0.42$ & Low validity \\
\hline $0 \leq x<0.20$ & Poor validity \\
\hline
\end{tabular}

Based on the interval for the instrument evaluation of communicative activities, it was shown that the communicative activities categorized as having very high quality. It was proven where the interval score was $0.76 \leq x \leq 1.00$. It means that the communicative activities designed have fulfilled the aspects of activities evaluation.

To know the quality of the communicative activities implemented, the questionnaires were distributed. The aim of distributing the questionnaire is to know both student's and teacher's perception regarding the existing activities. There were 28 students participated in giving their opinion toward the activities. They filled in the questionnaire which consisted of 30 questions. Regarding the questionnaire, the general statement stated by students were the activities used could make the classroom be more communicative, fun and enjoyable. During the learning process the students were actively engaged and felt motivated to learn English. Besides that, from the total 30 items of questionnaires, there were 22 items that got very agreed statement responses from the lecturer. It means that, those aspects in communicative activities provided have been appropriately designed.

\section{CONCLUSION}

This product was designed through the procedure of research and development which involves several steps. In designing the material was based on the theory of effective teaching materials proposed by Tomlinson (2013) and for the activities was based on theory of effective strategies proposed by Herrell and Jordan (2004).

The product has fulfilled the criteria of effective learning materials and criteria in designing the effective strategy for communicative activities. Moreover, the product was also considered to be effective in improving students' achievement which is highly motivated the students to learn by providing suitable materials in accordance with the students' needs and expertise.

\section{SUGGESTION}

Communicative learning material is believed as the material that can be effectively implemented in the classroom. Communicative material is closely related to authentic materials. Authentic materials are necessary because they are major condition of CLT that requires language expression of speaker's real world experiences.

Therefore, the English teacher should provide learning materials which based on the CLT approach and activities which could make students feel at ease to learn English, students have a desire to learn the language and day by day the improvement of students in learning English increased. The teacher needs to reconsider the learning materials and activities that will be used for teaching to avoid the boredom of the students. 
Further, the teacher must give many opportunities and space for their students to practice more. The rich learning environment gives students opportunities to spend their time to improve their skills. The expectations of the implementation of communicative learning materials supported by the activities are not only about students' motivation and spirits, but also the expectation of students' success in communicative competence in four language skills. Communicative activities provide students the opportunity to keep communication with learners, but the effectiveness of these activities not only depends on the teacher but also the students because they are the ones who are involved in the learning process.

For the other researchers, since this present study only for developing communicative learning materials for teaching English, hopefully, further study involves broader subject of the study need to be conducted. It also suggested that, it should be done in other field of study on the same institution or other institution and involves more companies. Since the present study only conducted at one institution as the target analysis which would not be enough for generalization.

\section{REFERENCES}

Adrienne L .Herrell \& Jordan, M. (2004). Fifty strategies for teaching english language learners (second). Pearson Education, Inc.

Cakir, I. (2004). Designing activities classrooms for young learners in efl classroom, 3, 101112.

Gao, Y. (2008). Implementing communicative activities in english reading class. Journal of English Language Teaching, 1(1), 14-18.

Hamed, R., Azri, A., \& Al-rashdi, M. H. (2014). The effect of using authentic materials in teaching. International Journal of Scientific and Technology 3(10), 249-254.

Howard, J., \& Major, J. (1995). Guidelines for designing effective english language teaching materials, 101-109.

Kim, D. (2008). The Effect of authentic English listening and reading materials on EFL learners, Multimedia-Assisted Language Learning, 11 (1), 61-84

Mary, E.Sugantha and Nirmala, J. . (2012). Second language acquisition enhances communicative competence. International Journal of Asian Social Science, 2(8), 12401242.

Ochoa, C., Cabrera, P., Quiñónez, A., Castillo, L., \& González, P. (2016). The effect of communicative activities on efl learners' motivation: a case of students in the amazon region of ecuador. Colombian Applied Linguistics Journal, 18(2), 39. https://doi.org/10.14483/calj.v18n2.10018.

Padmadewi, Ni Nyoman. (2013). Differenciated instruction and task based learning: Meeting the needs of hererogeneous students in a bilingual classrooms. The New English Teacher, 7(1), 46-67.

Peng, X. (2013). Communicative activities for practicing Chinese grammar in the lower level chinese class: a teaching portfolio. University of Oregon.

Phisutthangkoon, K. (2012). The use of communicative activities to develop english speaking ability of the first year diploma vocational students. University of Srinakharinwirot

Sugiyono. (2009). Metode Penelitian Kuantitaf, Kualitatif dan $R \& D$. Bandung: Alfabeta.

Tomlinson, B. (2013). Developing Material for Language Teaching. (B. Tomlinson, Ed.) (Second). Retrieved from www.bloomsburry.com

Trianasari, E. L. Y. (2015). Developing syllabus and material of english for mechanical engineering department at polytechnic of Banyuwangi. Ganesha University of Education.

Vijayasri. (2016). Authentic materials in the polytechnic English language classroom - 
teachers perceptions and practices. Journal of English Language and Literature, 3(1), 84-88. Retrieved from http://www.joell.in

$\mathrm{Wu}, \mathrm{Y}$. (2009). The application of CLT in college English vocabulary teaching. Journal of Cambridge Studies, 4(3), 128-131. 